\title{
About Inhabiting: Subjects, Objects and Habitable Space
}

\author{
Magda Mària ${ }^{1} \mid$ Pere Fuertes ${ }^{2}$ \\ Recibido: 04-12-2019 | en su versión final: 25-05-2020
}

\begin{abstract}
This paper retrieves the architectural and artistic proposals of the decades after World War II that - according to the main lines of thought of those years - redefine habitable space from the perceptive and emotional factors of the inhabiting subject. The objective is to demonstrate how these productions link their aesthetic and ideological contents with previous works but, at the same time, are consistent with recent proposals as they provide applicable responses to the needs of today's world. The revision of the texts of certain philosophers, as well as the re-reading of essays by architects and artists, constitute the theoretical framework that articulates the sequence of analysed works. Methodologically, the projects and the writings that support them are successively fed back into a path that not only involves the intimacy associated with the interior of the habitable space, but also the social and environmental relations established with the exterior and with nature. This transversal approach to habitability, interlacing different disciplines to address its redefinition, is one of the novelties of the research. The critical review of the positivist and hygienist parameters inherited from the Modern Movement that these works carry out from the logic of a sustainable humanism, along with the verification of the present validity of their statements and their contribution to the improvement of habitability are some of the main conclusions of this study.
\end{abstract}

Keywords: Habitability; domesticity; domestic architecture; domestic space; post-war architecture

Citation

Mària, M. y Fuertes, P. (2020). About Inhabiting: Subjects, Objects and Habitable Space. ACE: Architecture, City and Environment, 15(44), 9054. DOl: $\underline{\text { http://dx.doi.org/10.5821/ace.15.44.9054 }}$

\begin{abstract}
1 Associate professor, Department of Architectural Projects. Universitat Politècnica de Catalunya (ORCID: 0000-0002-3289-8746; WoS ResearcherID: ABB-4660-2020; Scopus author ID: 41762299800), ${ }^{2}$ Associate professor, Department of Architectural Projects. Universitat Politècnica de Catalunya (ORCID: 0000-00030477-5965; WoS ResearcherID: T-3130-2019; Scopus author ID: 56257814500). Contact e-mail: magda.maria@upc.edu, pere.fuertes@upc.edu
\end{abstract}

\section{Introduction}

To dwell is to build a place, to extend oneself over this place so that it responds as an echo to our actions and thoughts. By inhabiting, this double physical and psychic prolongation takes form; it constitutes the region of space that has been modified to our resemblance. Defined as the projection of the body and mind on a specific environment, the space inhabited in these terms is built from the

ACE, 15 (44.) CC BY-ND 3.0 ES | UPC Barcelona, España | About Inhabiting: Subjects, Objects and Habitable Space. 
inside, around the inhabiting subject, his gestures and movements, the relations he establishes with the objects that accompany him and the experiences that he undergoes. In this regard, the inhabited space has other dimensions than the strictly physical ones.

Different authors throughout the 20th century have addressed the experiential and perceptive nature of space. The work of August Schmarsow (1893) is especially premonitory, claiming a spatiality understood from within and incorporating the experience of the body and its movements, as well as its psychological and emotional requirements. Alois Riegl (1901) reviews spatial interpretations from antiquity and links the formal and constructive resolution of space with its optical-tactile understanding. Among the avant-garde movements, the publication of Lazlo Moholy-Nagy (1928/1985) stands out for defining space as 'the position relationship of the bodies' that are perceived with the senses - vision, hearing, balance and movement - in order to arrange it according to its own laws.

After World War II, Bruno Zevi (1948) rewrites the history of architecture based on the evolution of what he considers its main character the interior space, in which humans live and move. The formalisation, organisation and spatial construction over time condition its perception, experimentation, and use.

During the 1960s a drift towards an existentialist reading of space occurs. Based on the philosophical work of Martin Heidegger (1954) and Gaston Bachelard (1957) it is stated that existence is spatial, and that space is a contextual medium, thanks to which the disposition of things and their connectivity is possible. Philippe Boudon (1971) considers the coexistence between the 'lived' space and the 'thought' space as essential, the order of geometry being the vehicle that architecture uses to intermediate between the concrete and the abstract. Steen Eiler Rasmussen (1962) and Christian Norberg-Schulz (1971) deepen in the existential characteristics of space, in the order and sense it provides in vital relations and in its 'intangible' qualities and Cornelis van de Ven (1981) describes the direct involvement of philosophical currents of all times with architectural space.

\section{The habitable space}

These theories present the inhabited space as a mediator between void and bodies. They allow us to recognize the validity of actions as remote as the excavated houses in Matmata, Tunisia, or in the Loess Plateau, in central China, along with proposals as close as the organic Spray Plastic House by David Greene for Archigram in $1961^{1}$ (Figures 1 and 2). The action of excavating allows the inner space to be addressed integrally without palliatives, without distinguishing between walls and ceilings, without interposing the aggregative logic of materials. When building is a work of the subtraction of materials - or more properly, the introduction of space - man's room seems to rival with the area that quantum physics gives to the electron. The created place is an interior space, devoid of reversal, whose boundaries are limited to the dwelling from which they originate, establishing a total correspondence between to dwell and to build.

\footnotetext{
${ }^{1}$ The construction of the house is proposed in three phases: 1) carving a foamed polystyrene block of $40 \mathrm{ft}$ by $40 \mathrm{ft}$ by $15 \mathrm{ft}$ until obtaining a few certain interior volumes, 2) spraying over the surface of the interior space a fine layer of fibreglass, which will allow the initial material to be dissolved, and, finally, 3) equipping the resulting domestic space. Concerning the resulting 'soft' geometry, David Greene asks himself "why don't rabbits dig rectangular burrows? Why didn't early man make rectangular caves?” (Greene, 1962).
}

ACE, 15 (44.) CC BY-ND 3.0 ES | UPC Barcelona, España | About Inhabiting: Subjects, Objects and Habitable Space. 


\section{ACE Architecture, City and Environment}

E-ISSN 1886-480:5

Figure 1. Houses in Matmata, Tunisia

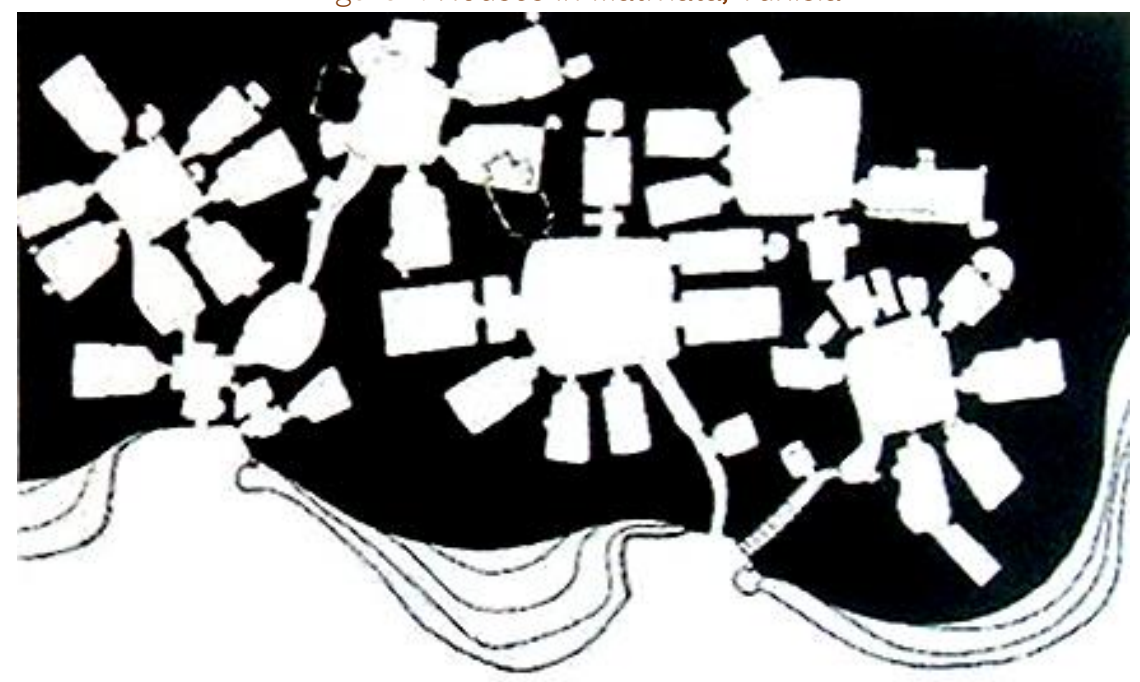

Source: DPA. Documents de Projectes d'Arquitectura, 13, 1997.

Figure 2. Greene, Spray Plastic House, 1961

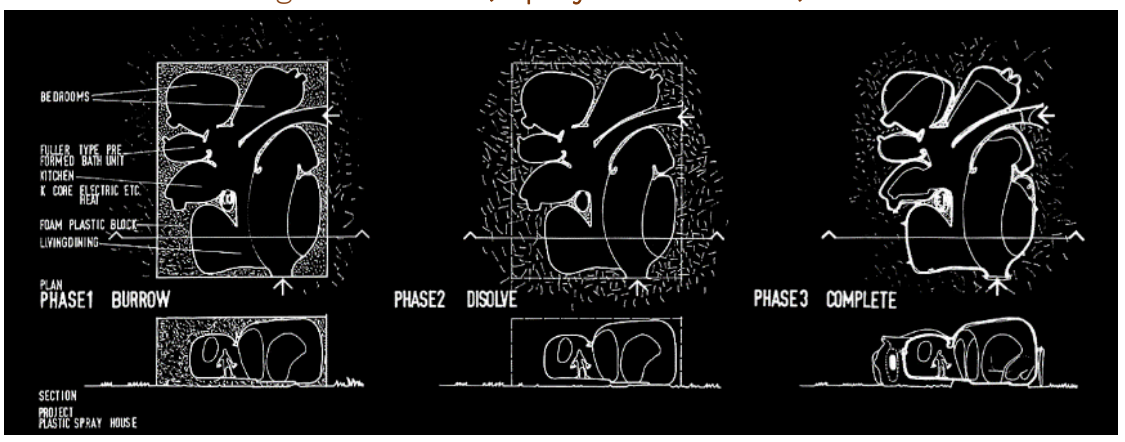

Source: http://archigram.westminster.ac.uk/

These rooms can now be observed with the same enquiring look that Luigi Moretti gave to the interior space in the early 1950s in order to make it visible (Bucci \& Mulazzani, 2000). For this purpose, he reversed the terms full and empty, solidifying the air and evaporating the mass that enclosed it (Figure 3) in a way that space adopts an unusual and specific presence for itself. It becomes a solid, tactile, apprehensible object; an 'orbital' of man's activity. In this way, Moretti brings us closer to the sensitive nature of the interior volume, which is perceived as independent of the properties and forms that the matter needed for its existence assumes. It is inspiring to imagine extracting a solid mould of the internal space of these excavated houses - like Pompeian calchi - as a way to address the complexity of the habitable environment.

In a way, this is what Greene proposed by dissolving the synthetic material which had provided an artificial ground for the emptying of the interior space of the Spray Plastic House, replacing it with a thin resistant shell, previously projected onto the inner surface. This way of operating - as stated by the architect himself - is analogous to the construction of burrows by certain animal species. It intimately relates the spatial needs of the users to the final morphological outcome. The resulting house transposes the empty volume to the exterior, reproducing its shape as a sum of convexities, evidencing that it has been shaped from the inside. Borrowing the words of Le Corbusier, "a building is like a soap bubble. This bubble is perfect and harmonious if the air is evenly distributed and properly ordered from the inside. The exterior is the result of an interior" (Le Corbusier, 1923, p.146). 


\section{ACE Architecture, City and Environment}

E-ISSN 1886-4805

Figure 3. L. Moretti. Structure and sequence of spaces

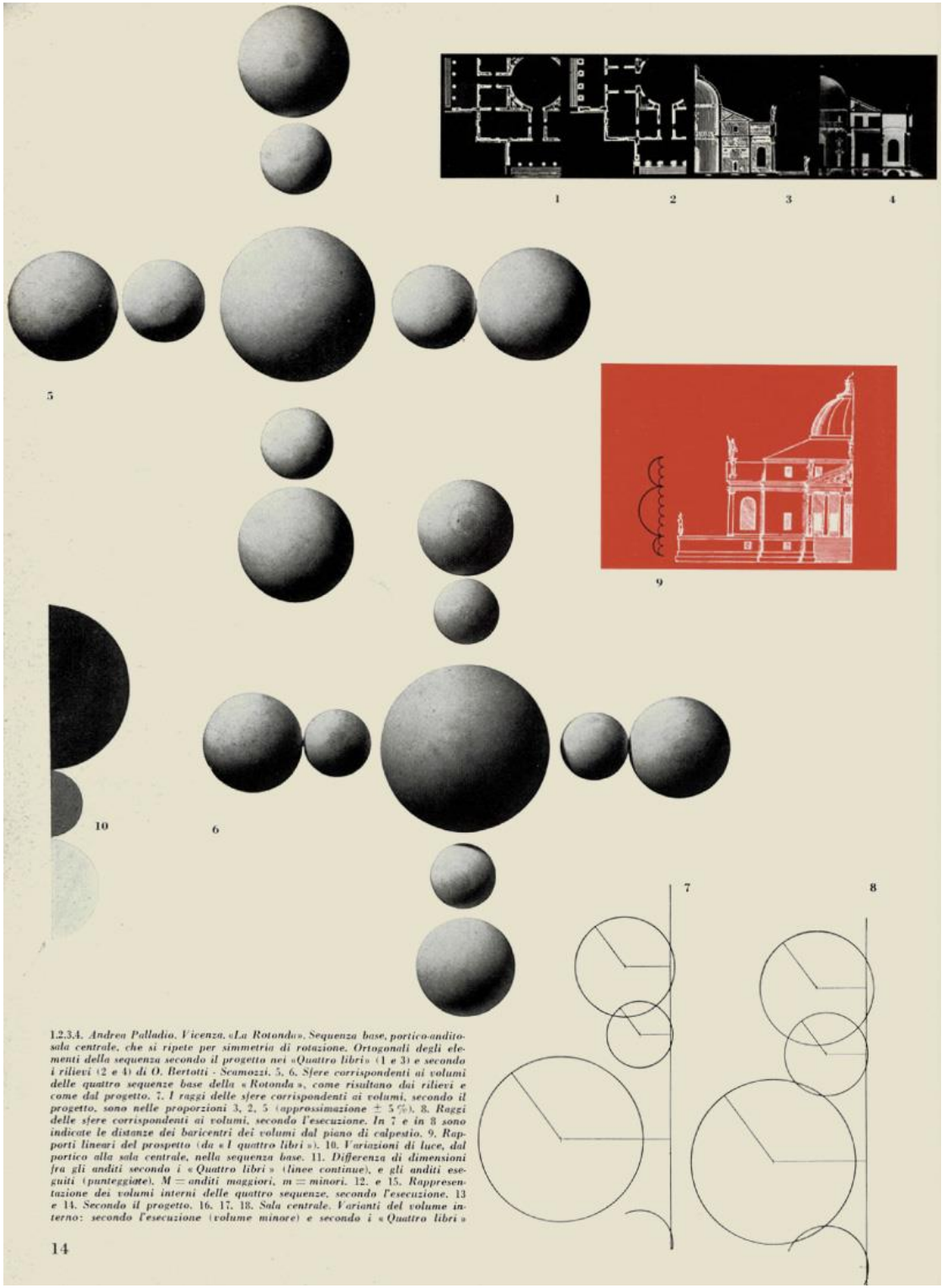

Spazio, IV(7), 1952-1953

In 1929, Le Corbusier had the opportunity to translate this idea into the scale of a room at a lecture held in Buenos Aires (Le Corbusier, 1930). On a grid of pillars - which places us in the ambiguous field of the free plan - he drew three enveloping figures, which he described as "les appartements privés" (Figure 4). He traces the area of every individual, of privacy, and does so by adapting to his profile and his movements, identifying a suitable contour for each subject regardless of the areas next to it. The living space is qualified by the delimiting gesture of the hand that draws it on paper, segregating it from the neutral space of the free plan, giving it its own identity. "The hand drew the envelope. Most tactfully, it drew it around the woman and the man. It enveloped their shapes and measurements. It did not only envelop them motionless, but it also surrounded their gestures, their movements, and their actions. It enveloped their thoughts... The envelope is not an arbitrary shape. Rather, it is formed by the life that it surrounds, just like the shell is" (Wogenscky, 1987). 


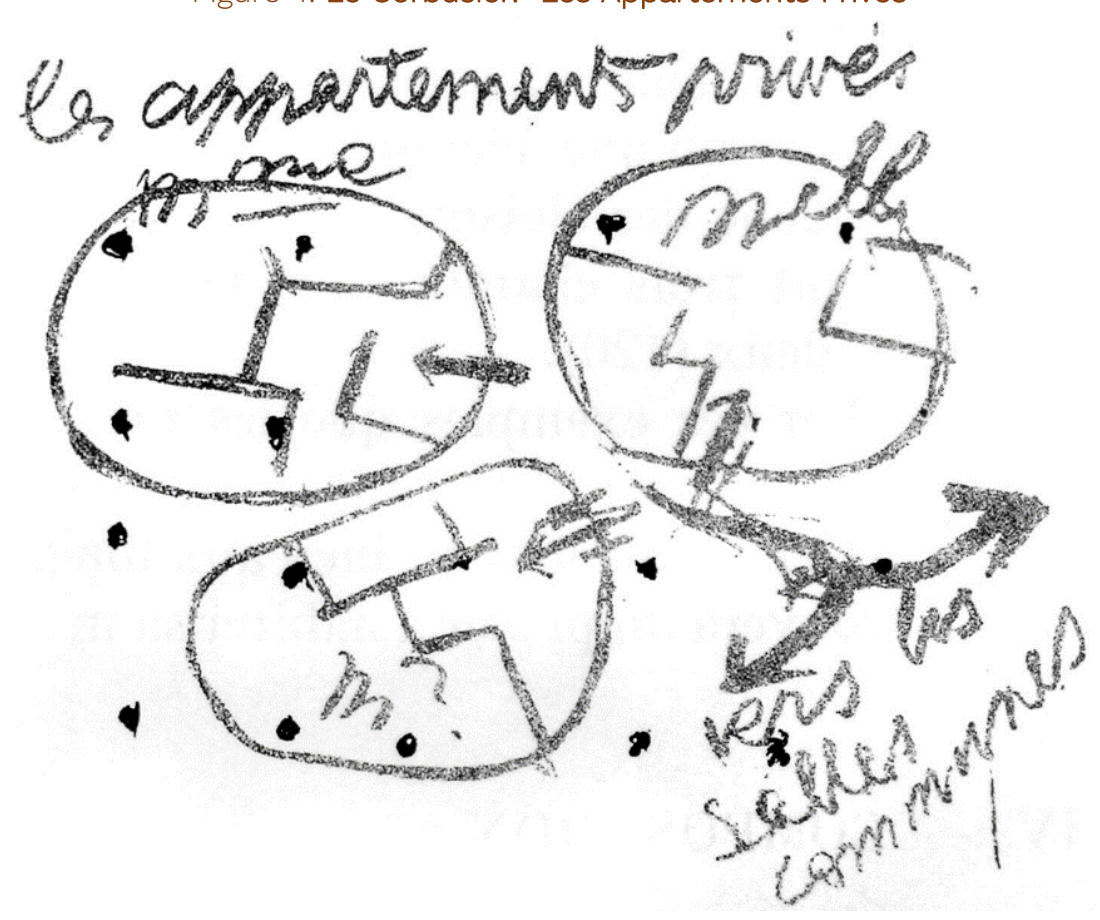

Source: Le Corbusier, Précisions, 1930.

As in the case of Greene, Le Corbusier literally transposes the form of the interior space to the external volume of each apartment, inverting the habitable concavities by convexities, which act as the reverse of a space whose first unit of measurement is the body itself.

It would be twenty-five years before the statement of intentions of these sketched contours would take shape in the first project of the Governor's house in Chandigarh, 1954, located on the third floor of the palace (Figure 5). Each of the apartments was conceived as a spiral built around an inhabitant and arranged autonomously, suspended in the fluid space of the house, in a slow drift that suggests an almost nomadic occupation of the vast area of the floor. The layout fits in like a second dress, next to the skin, as if the whole of the habitual gestures had the capacity to build, to model this environment as an enveloping surface in its image.

Frederick Kiesler defended for decades the correlation that should exist between the movements of inhabitants and the morphology of spaces, stating that "a house is a volume in which people live polydimensionally; it is the sum of every possible movement its Inhabitants can make within it" (Kiesler, 1949, p.739).

Through the Endless House (Figure 6) - a project initiated in 1949 and never completed - Kiesler tested through different models the ability of architecture to combine form and content, to guarantee through domestic space the coordination of physical conditions with the psychological, social, mystical and even magical needs of the subject. The house as a living creature - as an epidermis of the human body - thus becomes the abode of the phenomenon, the place of happenings, the shelter of events changing through time. "The events of life are your house guests [...] you receive them with open arms, and they become you. You are fused with them and thus reinforced in your power of selfreliance" (Kiesler, 1966, p.567). 


\section{ACE Architecture, City and Environment}

Figure 5. Le Corbusier. Governor's Palace, Chandigarh, 1954

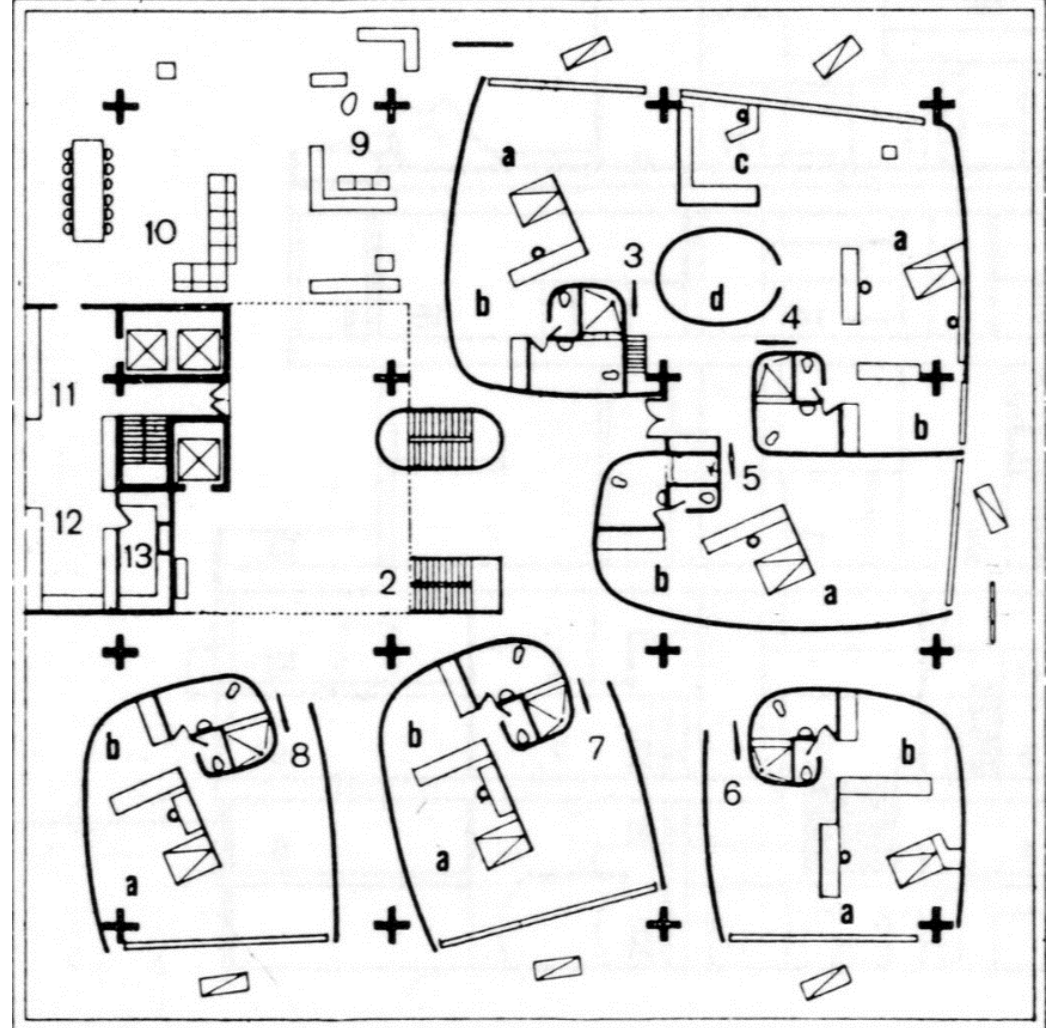

Source: Le Corbusier, CEuvre Complète 1946-52, 1957.

Figure 6. F. Kiesler. Interior model of the Endless House, 1959

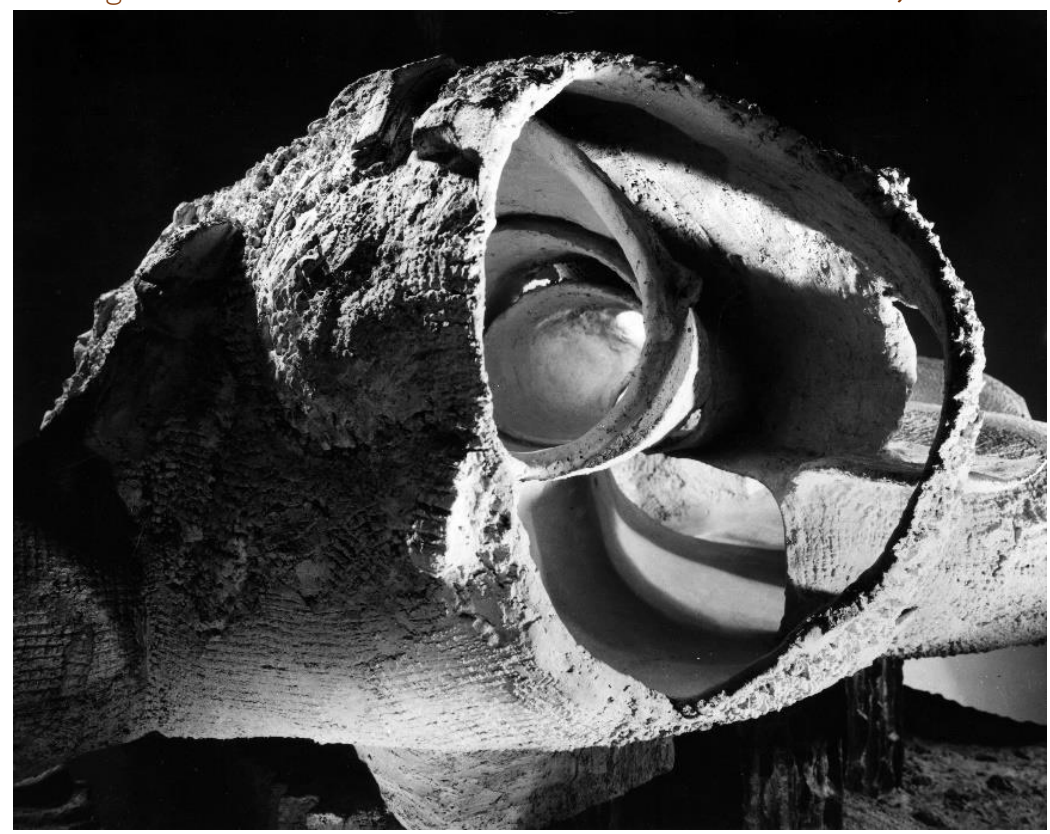

Source: Frederick and Lillian Kiesler Private Foundation, Vienna.

The enclosure - of clear cavern connotations - that Kiesler obsessively represented through the Endless House, is a transposition of the environment that protects the subject during his comfortable

ACE. 1.5 (44.) CC BY-ND 3.0 ES | UPC Barcelona, España | About Inhabiting: Subjects, Objects and Habitable Space. 6 DOI: http://dx.doi.org/10.5821/ace.15.44.9054 
existence inside the womb, throughout his gestation. Gaston Bachelard refers to this when comparing caverns to the safety and protection provided by the maternal womb. This spatial memory, this primitive abode, is preserved by the subject and forms an indissoluble part of his personality, "fused" within him forever. It emerges recurrently through our memories or the evocations that occur when experiencing certain spatial events: "in the little nooks we find shade, rest, peace, rejuvenation [...] all the resting places are maternal” (Bachelard, 1946, p.111).

\section{Building the dwelling space}

In 1951, two years after the start of the Endless House, but also coinciding with the appearance of Moretti's spatial sequences and Le Corbusier's project for the Governor's Palace in Chandigarh, Martin Heidegger's "Building Dwelling Thinking" was published. Partially gathering a series of theories developed from earlier texts, Heidegger brilliantly argues in this work the inevitable link between being and time and, therefore, the commitment of architecture to accommodate not so much to the static but to the changing events.

For the German philosopher, the purpose of the building is to respond spatially to a series of values that should be part of our vital and changing everyday life. Rethinking the ultimate meaning of dwelling, he concludes, among other things, that "only if we are capable of dwelling, only then can we build" (Heidegger, 1954, p.156). He extensively argues this statement by analysing the origin of the terms dwell and build. Dwell - in German wohnen - is different from live - leben -, clearly distinguishing one action from the other. In turn, the verb build - in German bauen - comes from the old term buan, which means 'to dwell, reside, stay'. Buan, therefore, is equivalent to wohnen: dwell and build mean essentially the same.

However, Heidegger's conclusions do not end here. The correspondence between buan and the German conjugation of the verb to be: Ich bin, du bist ... (I am, you are ...) in turn identifies build with to be and consequently, be with dwell: "the manner in which we humans are on the earth is buan, dwelling" (Heidegger, 1954, p.143).

The necessary confluence between building, living and being claimed by Heidegger in a lecture in 1951 is a catalyst for the current parameters of habitability, a legacy inherited from the prevailing positivism and hygienism since the early decades of the twentieth century. Occupied with resolving living spaces endowed with environmental conditions and enough services to meet the most basic physiological requirements, the vast majority of dwellings designed hitherto did not consider amongst their project premises neither the identity of the subject to inhabit the space nor his subjective, intimate and personal needs.

But Heidegger's writing not only put in crisis the conditions that the immediate past imposed on the act of building in order to dwell - including something so difficult to quantify as the experience and way of being of the existential subject - but also anticipated in a premonitory way what inhabiting the earth currently entails. It is remarkable how the four parameters required to dwell in the world, named by the philosopher as das Gevier (the fourfold), coincide with certain attitudes that today are considered essential for assuming a responsible life with respect to other humans and the planet:

- $\quad$ On the earth leads us to save the world, not to take possession of it or submit it, to respect its materials and qualities. To dwell on the earth also means to establish a relationship with landscape, to reach the essence of places, to harmonize buildings with nature and traditions of their place. An example of this would be the Todtnauberg hut, in which the philosopher spent long periods of time since 1922 (Figure 7).

ACE, 15 (44.) CC BY-ND 3.0 ES | UPC Barcelona, España | About Inhabiting: Subjects, Objects and Habitable Space.

DOI: http://dx.doi.org/10.5821/ace.15.44.9054 


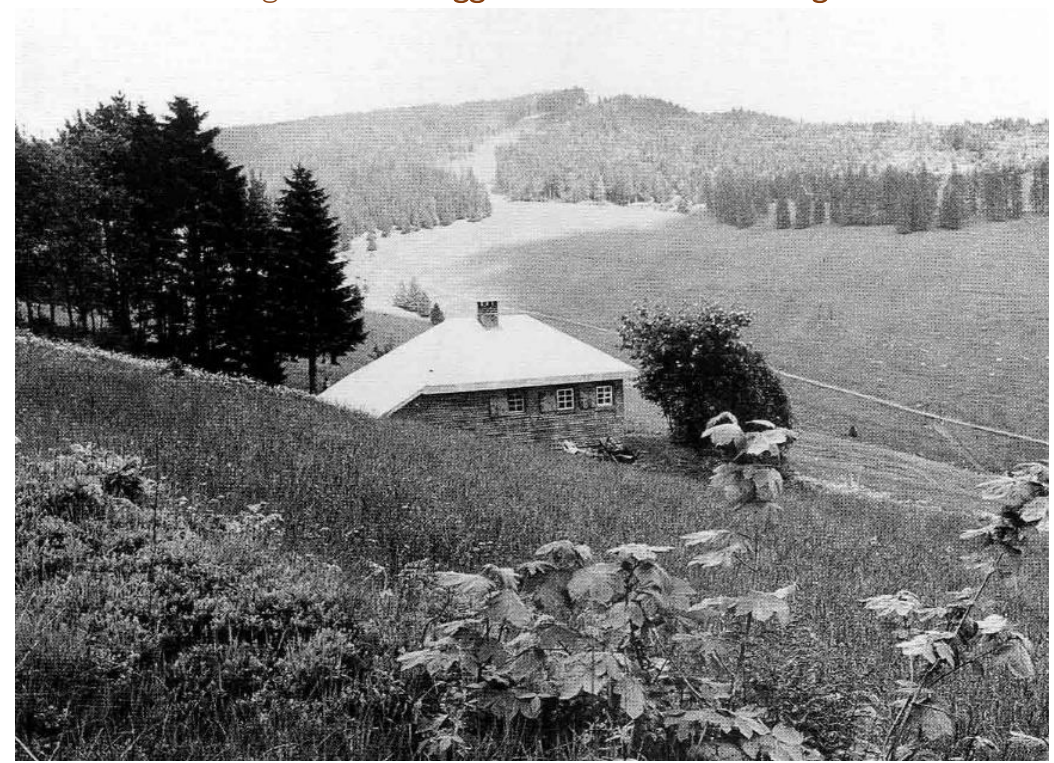

Source: Digne Meller-Marcovick, 1966

- Under the sky invites us to embrace the laws of natural order coming from the atmosphere, the sun, the stars and the seasons. Dwelling under the sky involves adjusting to the inclemency of the weather and taking advantage of the resources that nature provides for us, to dialogue with them and accept them as they appear.

- Before the divinities presents the possibility of contemplation, to transcend the material facts within our daily life. To await the divinities as divinities means to keep an open spirit, to be willing to dispense with superfluous comforts in order to recognize the essence of existence, to be able to banish false idols in order to open up space for immanence.

- Among mortals roots us to our own finitude, to our temporality, to our time on earth, to our nature as beings capable of death as death. But it also relates us to others, to our capacity to live in society, to establish dialogue, to communicate, to collaborate and to be enriched by the experiences of others.

Dwelling is defined by Heidegger as "the fourfold preservation of the fourfold" as the ability "to look after the fourfold in its presencing" (Heidegger, 1954, p.145). Dwelling means harmonising these four principles through existence. Building is establishing the adequate parameters to shelter this fourfold and, therefore, to proceed accordingly. ${ }^{2}$

Two decades after the publication of Heidegger's essay, the similarities between dwelling, building and being, stated by the German philosopher are also present in the definition of the room by the architect Louis I. Kahn. The drawing significantly entitled "Architecture comes from the making of a Room" (Figure 8), in the same year, perfectly illustrates Kahn's words: "the room is the beginning of architecture. It is the place of mind. You in the room with its dimensions, its structure, its light responds to its character, its spiritual aura, recognizing that whatever the human Proposes and makes becomes a life" (Kahn, 1971, p.33).

2 The fact of Inhabiting intimately connected with a deep sense of respect for the earth and nature is present a decade earlier in the work and thought of the German architect Rudolf Schwarz. Inhabiting, he wrote in 1940, means "to be in harmony with the life of nature, cure the chaos in it, heal what is deviant". This concern led him to consider the fact of amending what he calls the wounds that are vested to the earth during excavation work: "Do we not perhaps start our buildings as a transgression?" (Schwarz, 1940).

ACE, 15 (44.) CC BY-ND 3.0 ES | UPC Barcelona, España | About Inhabiting: Subjects, Objects and Habitable Space.

DOI: http://dx.doi.org/10.5821/ace.15.44.9054 
Figure 8. L.I. Kahn. Architecture Comes from the Making of a Room. 'City/2' Exhibition, 1971

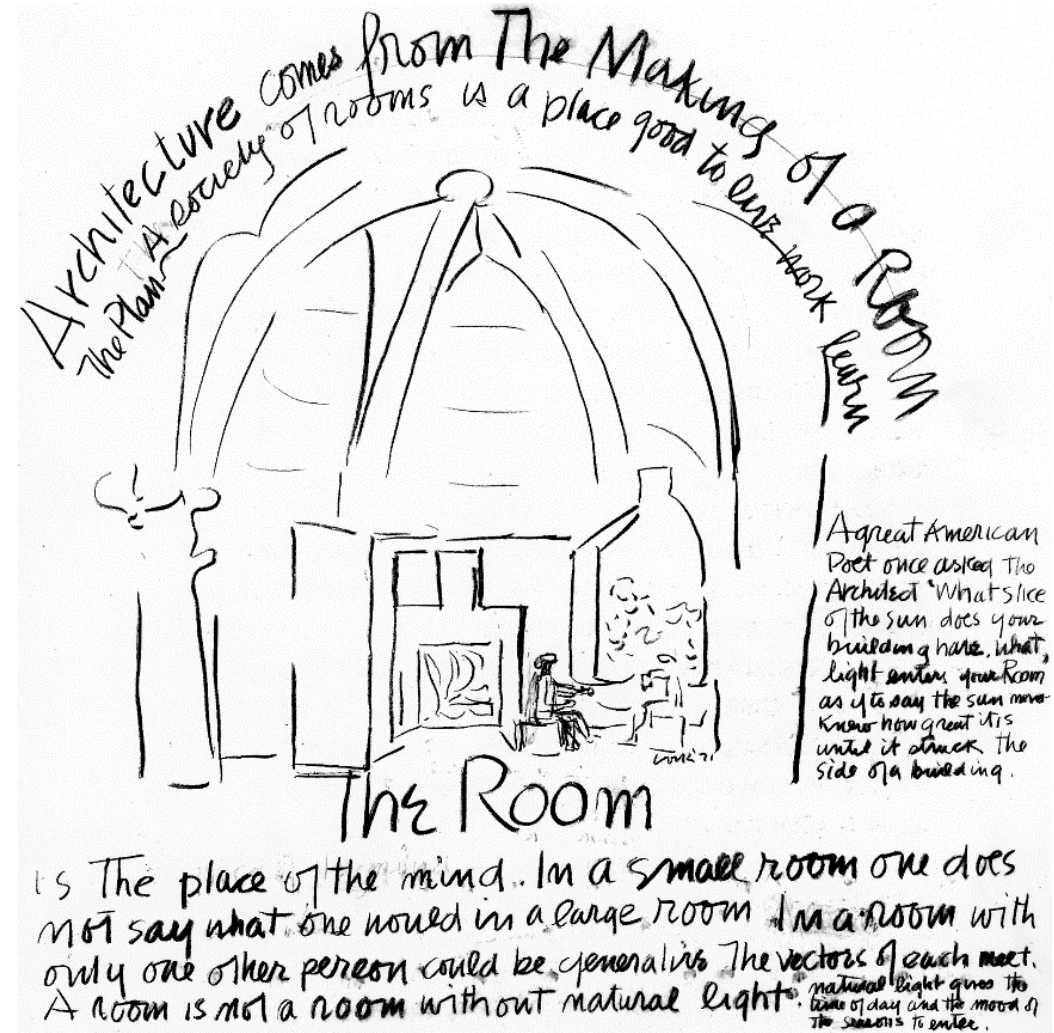

Source: Philadelphia Museum of Art, Gift of the Artist.

The architect defines the room that houses life, not only as a physical place but also as a mental place. Architecture involves the vital concerns and the spiritual life of those who live there: the container and the users interact, empathise, identify with each other, as part of an indivisible whole.

It is no coincidence that the term Room comes from the German term Raum, a word which Heidegger signals etymologically coming from Rum, which means space, in the sense of "something that has been made room for, something that is cleared and free" (Heidegger, 1954, p.149). For the German philosopher, Raum implies the germinal idea of the inner impulse, it responds to the fact of making space, of configuring the living environment from the interior. An idea, which Kahn also shares by conceiving the form of the rooms in response to the drive that comes from the inside.

Room, therefore, is built from this internal pulse coming from the inhabitant, who organizes, weeds, and clears the places until the limits are reached. In them, on the boundary of this spaced room, it is "that from which something begins its presencing" (Heidegger, 1954, p.150). It is precisely at the beginning of this essence, in the definition of these measurable, tangible limits, linked to the construction process, where - according to Kahn - architecture begins to operate.

The drawing of the room describes with a few strokes the architectural elements that compose this area. However, at the same time, these limits drawn by Kahn evoke the referential need announced by Heidegger to preserve the fourfold, thus enabling the act of dwelling:

- $\quad$ The ground that sustains the built premises and the scene that takes place inside it, exemplifies the respect that Heidegger demands for saving the earth, for placing the abode on the land

ACE, 15 (4.1) CC BY-ND 3.0 ES | UPC Barcelona, España | About Inhabiting: Subjects, Objects and Habitable Space. 
without harming it. The open window in one of the walls gives a glimpse of nature and the dialogue that is established with it through the room.

- The vaulted ceiling that covers the room has been described as an analogy of the sky-dome (Kohane, 2002). Its hemispherical shape shelters a dwelling under the sky, ready to receive the laws of natural order that come from the atmosphere.

- The polygonal walls approaching the semicircle, together with the dome culminating in a circle that can be either an oculus or a keystone, leave an open empty centre, devoid of objects, ready for awaiting the divinities.

- The two people talking by the window, comforted by the warmth of the fireplace, personalize the temporality of the phenomenon, making us aware of the provisional nature of existence but, at the same time, entering into a relationship with mortals through their conversation, but also by opening onto the world through the ajar door and the open window.

The space described in the drawing is a dwelling-space which, unlike the Euclidean space-extension in which we can establish abstract relations in the three directions, enables its being inhabited, welcomes the phenomenon, and provides the ideal framework for life to unfold. The dwelling-space goes far beyond the strict function, overcoming it, extending it, humanising it. This has to be read from the beginning of the project, from the drawings produced by the architect: "for musicians, their writing means something more: it means sound, it means the organization of sound. The architect must be able to read, through his plans, the implication on life of his works" (Kahn, 1959).

It is not by chance that this domestic space represented by Kahn is covered by a dome. The vaulted space is - according to Giedion - the protagonist of the second age of architectural space since it has represented the sheltering capacity of architecture in the Western world for more than two thousand years. The simplest containers, a cup or a bowl, have the same primitive form as the dome (Giedion, 1971).

The identification of the concavity that covers the room drawn by Kahn with the shape of a cave or a container as an emptied interior evokes two references. On the one hand, the place in which we remember the most primitive feelings of comfort and shelter. On the other hand, the allusion to a dome links us to the architecture that for centuries has culturally and historically defined the epitome of interior space.

The French philosopher Gaston Bachelard identifies the vaulted forms of cellars and caves with those of the human skull. ${ }^{3}$ Thus, the roof of the room represented by Kahn would coincide with the limits of the mind. The phrase that accompanies the architect's drawing "the Room is the place of the mind" (Figure 8) acquires its full meaning here. Hence, by taking possession of the shelter, by inhabiting the room, however small or modest it may be, we take possession of a world: our own world. Our vernacular and cultural references appear and yet our own personal identity crystallizes.

For Bachelard, images that refer to the identification of the subject with himself, with things, or with the universe, are isomorphic, thus becoming metaphors of each other. In this sense, the analogy between the feeling of refuge inside the room and the maternal body turns the ceiling into a womb. But, at the same time, this intimate abode is also identified with the cosmic immensity: "Saintyves asked himself whether the caves were not considered in the Quaternary period as a reduction of the cosmos, the dome representing heaven and taking the floor for the whole wide world. It seems very

\footnotetext{
3 The sentence quoted by the author comes from the story of Jonah: "The vault, with its almost brain lobes and its rampant ramifications similar to the flowerings of the nerves, had a tender reflection of crisoprasis" (Bachelard, 1946, p.149).
}

ACE, 15 (4.1) CC BY-ND 3.0 ES | UPC Barcelona, España | About Inhabiting: Subjects, Objects and Habitable Space.

DOI: http://dx.doi.org/10.5821/ace.15.44.9054 
likely to him that certain caves have been excavated and made adequate according to the rules of an architecture which should reflect the image of the Cosmos" (Bachelard, 1946, p.174).

The concavity of caves becomes a kind of universal matrix in which the individual recognizes himself in his history and his origins in an unconscious way. But the vaulted rooms also acquire the capacity to transmit sound, to act as a soundboard, thanks to which, when the sense of sight is obscured by night, the sense of hearing is enhanced. Hearing "reveals transcendences [...] is the sense of the night $[\ldots]$ the caves give out the most sensitive of echoes [...] the smallest cavern offers all the reveries of resonance. [...] The cave is not in this case more than a resonator, a soundboard. But the artificial cave is asked to strengthen the voices of wind because they have been dreamed of in the threshold of the resonating caves" (Bachelard, 1946, p.170).

\section{The lateral functions of dwelling}

The Spanish architect Juan Navarro Baldeweg uses the same terms as Gaston Bachelard to refer to what he calls the lateral functions of dwelling. He calls the rooms in which the subject dwells soundboards since life must be able to resonate with all its musicality inside them. In accordance with this idea, in 1976, Navarro Baldeweg took part in an exhibition entitled "Light and Metals" in the Vinçon Gallery in Barcelona, installing a swing suspended at one of the limits of its oscillation. For the author, this device has the ability to evoke the feeling of weightlessness experienced during childhood, the lightness and the progression of the transported body, and the different perceptions of air and light achieved through movement.

The installation (Figure 9) takes place in a room in which, besides the swing, a large window - divided into rectangular fragments - opens on one of the walls while in another wall section a large door gives access to the premises. Surrounding the window and also following the walls, a number of coloured lines extend centripetally or cross with each other in a recurrent way. They are personal signs of those who inhabit this space, a sort of graffiti that expands the action of the hand, as a witness to the energy and expressiveness of the person who has appropriated the room.

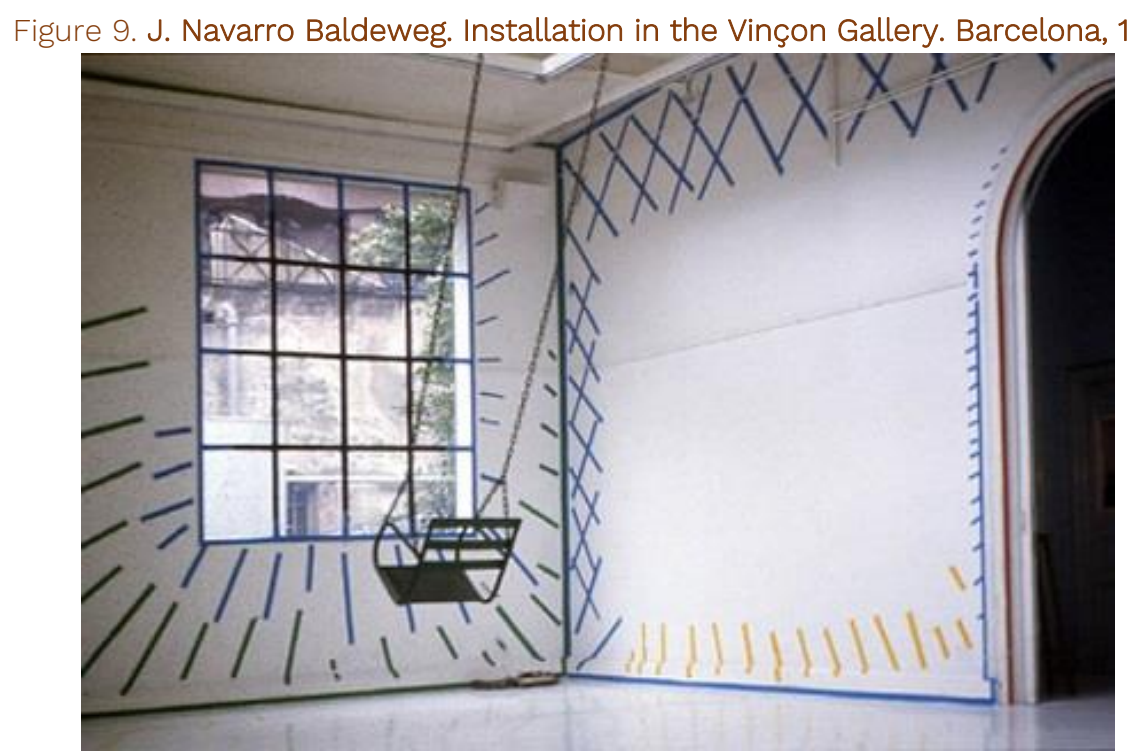

Source: Juan Navarro Baldeweg, La habitación vacante, 2001.

ACE, 15 (44.) CC BY-ND 3.0 ES | UPC Barcelona, España | About Inhabiting: Subjects, Objects and Habitable Space. 
This vacant room can be considered an analogy of inhabiting. Its ingredients are the swing - with all its evocative charge in motion - the window that opens to nature and the atmosphere, the door that relates to society and the rest of the world, and the scribbles - which are traces of the subject's energy. In fact, in almost identical terms to other authors, Navarro Baldeweg explains how the act of inhabiting a room involves a committed, conscious, and active relationship which travels in two directions: we inhabit, and we are inhabited. "Inhabiting and room [in Spanish habitar and habitación] are two sides of the same phenomenon: there is a mutual dependence, a circularity between both, and architecture should always be considered simultaneously in this dual approach" (Navarro Baldeweg, 2001, p.13).

The poet Noël Arnaud expresses himself in a similar way, identifying the inhabitant with his dwelling when he says "je suis l'espace ou je suis" (I am the space where I am) (Bachelard, 1957, p.164). It is Bachelard who recurrently claims the unconscious roots of dwelling and, therefore, the identification with what he defines as the oneiric house: "the act of living is covered with unconscious values, unconscious values that the subconscious does not forget" (Bachelard, 1946, p.108).

This interdependence between dwelling, building and being, expressed by Heidegger and graphically illustrated by Kahn, reappears in the installation of Navarro Baldeweg under the disguise of other signs. Using a specific spatial context in which the phenomenon can be experienced as it happens; the Spanish architect shows the capacity of rooms to exceed mere functionality, embracing what he describes as lateral functions, which are none other than those that intensify the experience. Rooms thus become soundboards in which life occurs (Navarro Baldeweg, 2007).

The paintings of Jan Vermeer and other artists from the Delft school provide images that are conceptually identical to that of the photographic moment when the swing stops to continue its motion (Muñoz Millanes, 2001). The inclination of the balance in the hands of a young woman weighing a pearl, or the fragility of the letter held by the girl reading it (Figure 10), show Vermeer's ability to capture this magical instant in which action is suspended. As in the snapshot of the swing, time comes back to life thanks to the subtlety of the light rays, which penetrate illuminating the essence of the scene and evoking the events beyond the window. A leaded window divided into rectangular fragments, like those reproduced by Navarro Baldeweg.

The analogies of the installation "Light and Metals" captured in the snapshot of the swing can extend to different episodes in the history of painting. The celebration of life defended by Navarro Baldeweg as the ultimate aim of architecture (Navarro Baldeweg, 2008), is the subject of many paintings by Vilhelm Hammershøi. They show the capacity of interiors to embrace phenomena beyond mere functionality, transcending everyday chores. The Danish painter, like the master of Delft, uses in an almost iconographic way the presence of a woman, usually from the back or in profile, inside a series of domestic spaces bathed in light and complemented by few but meaningful objects.

In one of his paintings - mirroring Vermeer's work - a girl is in profile reading a letter in front of an open door (Figure 11). Light is focused on the white walls, on the tablecloth, on the china, and on her own apron; it bathes the emotion contained in her face and the tension of her hands. The open door, in an analogous way to Vermeer's paintings, stands as a metaphor for the outside world announcing an absence through the fragile presence of the letter, which echoes in the intimacy of the house and the objects it shelters, thanks to the mediation of the room.

ACE, 15 (44.) CC BY-ND 3.0 ES | UPC Barcelona, España | About Inhabiting: Subjects, Objects and Habitable Space. 


\section{ACE Architecture, City and Environment}

E-ISSN 1886-4805

Figure 10. J. Vermeer. Young Woman Reading a Letter, ca. 1657

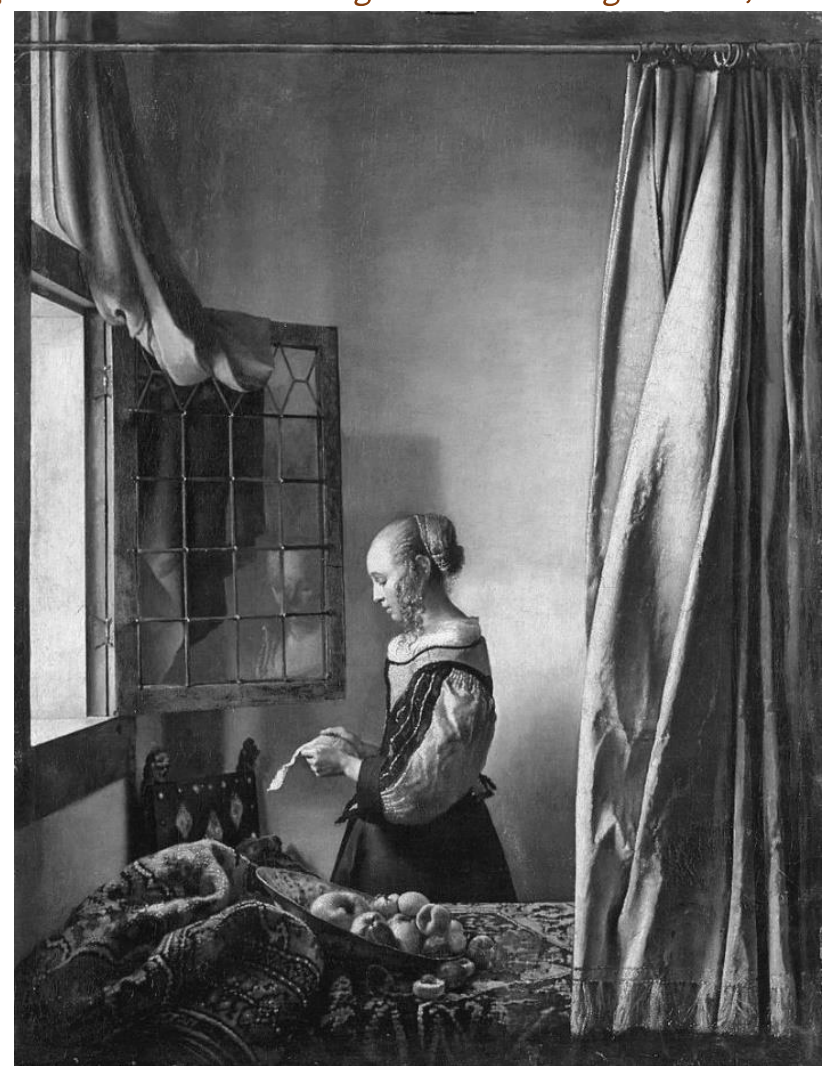

Source: https://en.wikipedia.org/wiki/Girl Reading a Letter at an Open Window

Figure 11. Hammershøi. Ida Reading a Letter, 1899

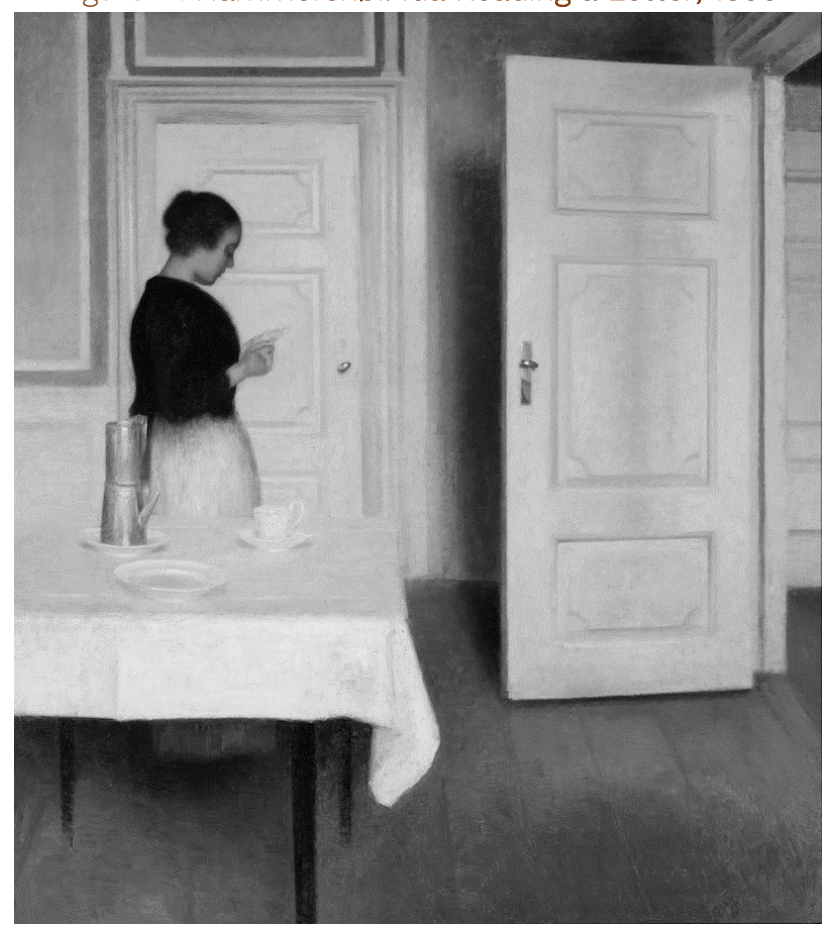

Source: https://en.wikipedia.org/wiki/lda Reading a Letter

ACE, 15 (44:) CC BY-ND 3.0 ES | UPC Barcelona, España | About Inhabiting: Subjects, Objects and Habitable Space. DOI: http://dx.doi.org/10.5821/ace.15.44.9054 


\section{Inhabiting and the objects}

In the spring of 2009, the Playground theatre company began to stage the show "A taula!" (To the table!), a trilogy of works intended to reveal the atmosphere of the spaces we inhabit. ${ }^{4}$ The first performance explored the role played by objects used at the table during a meal. The scenic and visual mechanisms used throughout the work focus mainly on dishes, bowls, cups, glasses, silverware, pots, and other objects belonging to different antique crockery (Figure 12). Actors - conveniently dressed in black - show only their hands and, occasionally, the expression on their faces, in order to give all the prominence to the utensils that, first in a cabinet, and then on the table, would only be mere instruments, if not because their role goes beyond simple functionality.

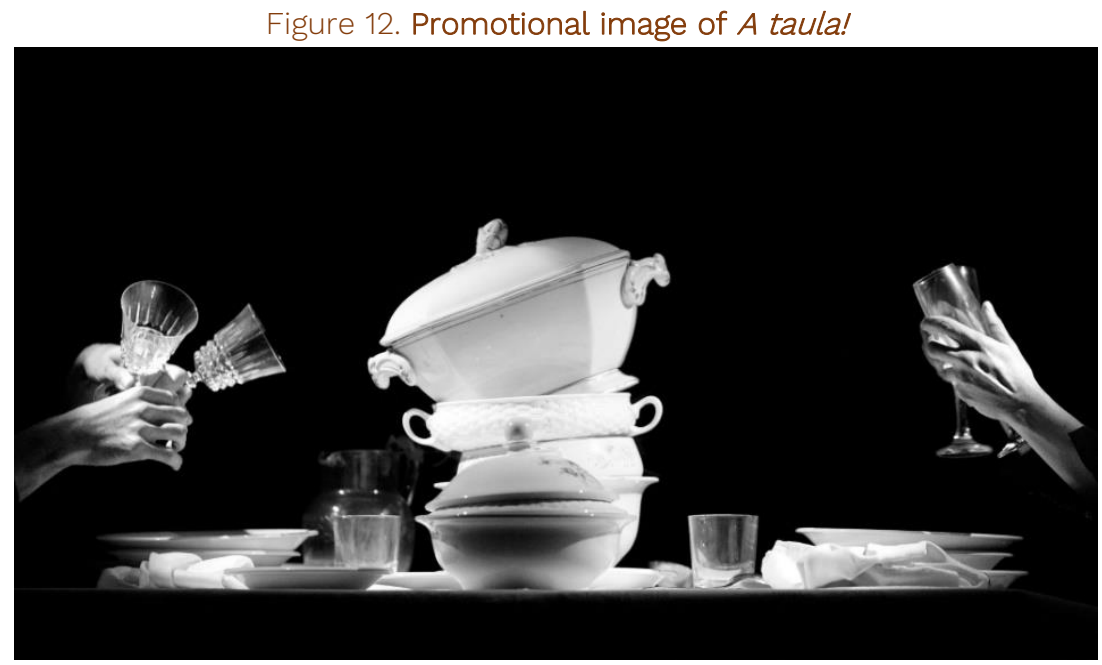

Source: Jordi Bover, http://www.playgroundvisual.com/

Through their movements and position, viewers follow the development of the events. Objects convey the harmony or tension of the guests, in them merge the desires, miseries or excesses of those who use them. The pieces of crockery, glassware or cutlery - many of them fragile and brittle - are the absolute extension of the daily chores throughout the play. Their abiding presence in the domestic space, converts them in both witnesses and protagonists of inhabiting.

The field of art installation is particularly fertile for exploring the relationship of dwelling with ways of being and feeling, with everyday objects and how these occupy space. The works of Canadians Janet Cardiff and George Bures Miller are an outstanding example of it. By means of the changes in lighting, musical pieces, sounds, voices, smells and small movements of objects that come alive activated by invisible mechanisms, this duo of artists recreates atmospheres that appear as vacant rooms in which experiences, time, memories, external references, and ultimately, the lives of their inhabitants are echoed.

In one of their productions created in 2005, entitled "Opera for a Small Room" (Figure 13), we furtively observe the crowded room of a music collector from the outside. For over twenty minutes, we experience the atmosphere of the room, the transit of events that take place in it. We perceive the pulse and mood of the collector, hearing his voice, his footsteps and the musical pieces of his existential journey. We breathe the mould of the objects which, steeped in history, acquire an unusual prominence throughout the narrative. We tremble as the trains pass by at nightfall and feel protected

4 This is a visual theatre production that addresses the everyday objects that surround us in the domestic space. "A taula!", play by Xavier Bobés/Playground. Sets and props by Sandrine Veyry. Espai Lliure. Barcelona, Cycle 'Radicals', May 2009.

ACE, 15 (44.) CC BY-ND 3.0 ES | UPC Barcelona, España | About Inhabiting: Subjects, Objects and Habitable Space. DOI: http://dx.doi.org/10.5821/ace.15.44.9054 
by the warmth of the place when the rain beats its limits. This is how art can express the essence of living, and it is from these writings, these installations and these paintings that architecture should contaminate itself in order to build the appropriate frameworks for life to resonate amplified in its interior.

Figure 13. J. Cardiff, G. Bures Miller. Opera for a Small Room, 2005

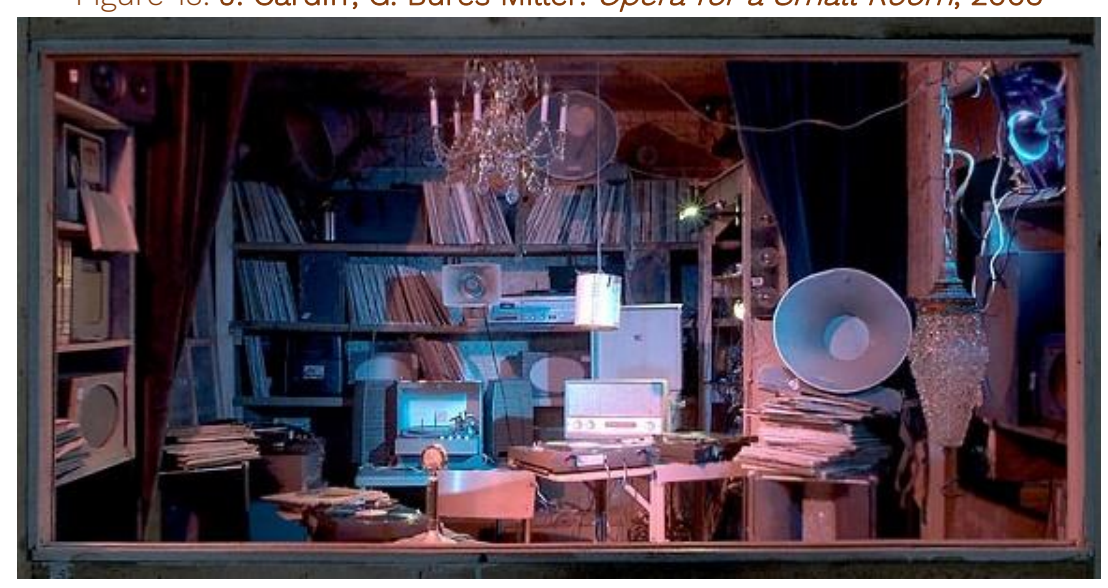

Source: Janet Cardiff and George Bures Miller.

Objects have the rare quality of revealing the presence of the inhabitant. In a 1956 installation by British architects Alison and Peter Smithson entitled "Patio \& Pavilion", they explained through these two elements the qualities that - according to them - are an essential part of human inhabiting. The patio represents human needs for connection with the world and with others. The pavilion expresses the requirements of privacy, intimacy and introspection.

In this installation, everyday objects become latent presences that complement and even define the identity of the inhabitant; they stand as silent witnesses that, when activated, express affection, evoke memories, and reveal parallel realities (Figure 14). The Smithsons expressed their opposition to the consumerist vortex that began to emerge in the middle of the last century and which rapidly devalued all the qualities historically associated with everyday objects. They claimed for the slow pace that allowed to savour day by day the relationships with things, beyond their materiality. Each object had a suitable place in the habitable space; each daily act acquired the attention and time required to give meaning to its existence. As it happens during the same period in Van Eyck's domestic work especially in his own houses - objects build spatial relationships, give meaning to the inhabited space, and acquire a symbolic value according to the connection he establishes with them (Uribe et al, 2020).

When an alteration in the relationship of objects with space occurs, it is possible to understand the delicate balance between this particular 'portrait' and the inhabitant himself. In his 1980 work entitled "Autobiography", Sol LeWitt photographed and catalogued over a thousand images of the objects that filled his New York apartment before he left for Florence (Figure 15). The thoroughness of the inventory allows the North American artist to make a detailed self-portrait through the objects that extend his identity. However, the format he uses - thematic series of nine images - and their subsequent systematic exhibition deliberately nullify the relationship that the objects once established with the space and the inhabitant. The 'portrait' thus decontextualised resents this lost relationship; everything is there, but only the author can recall, from the images, the life he left behind. For other observers, objects are a fascinating material that is only activated in the new proximities created by the exhibition. The life they relate is a careful impersonation of real life and, despite being shown in the slightest detail; it preserves to LeWitt himself the dwelling that originated it.

ACE, 15 (44.) CC BY-ND 3.0 ES | UPC Barcelona, España | About Inhabiting: Subjects, Objects and Habitable Space. 


\section{ACE Architecture, City and Environment}

E-ISSN 1886-480

Figure 14. A. \& P. Smithson, Patio \& Pavilion, London, 1956

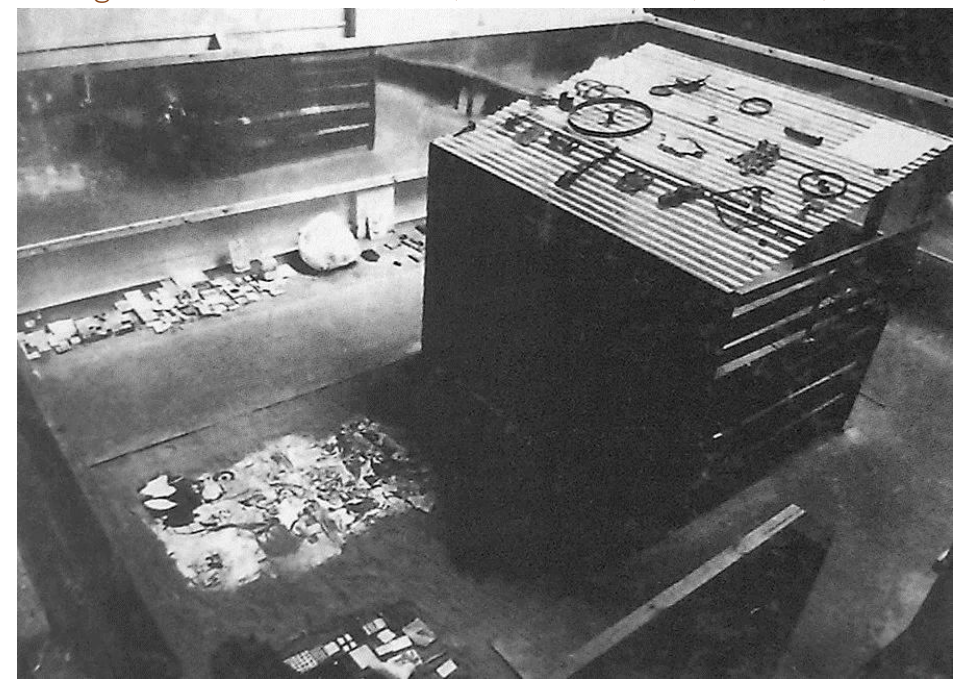

Source: N. Henderson and E. Paolozzi, Patio and Pavilion. This is Tomorrow (London, 1956).

Figure 15. S. LeWitt. A page of Autobiography, 1980
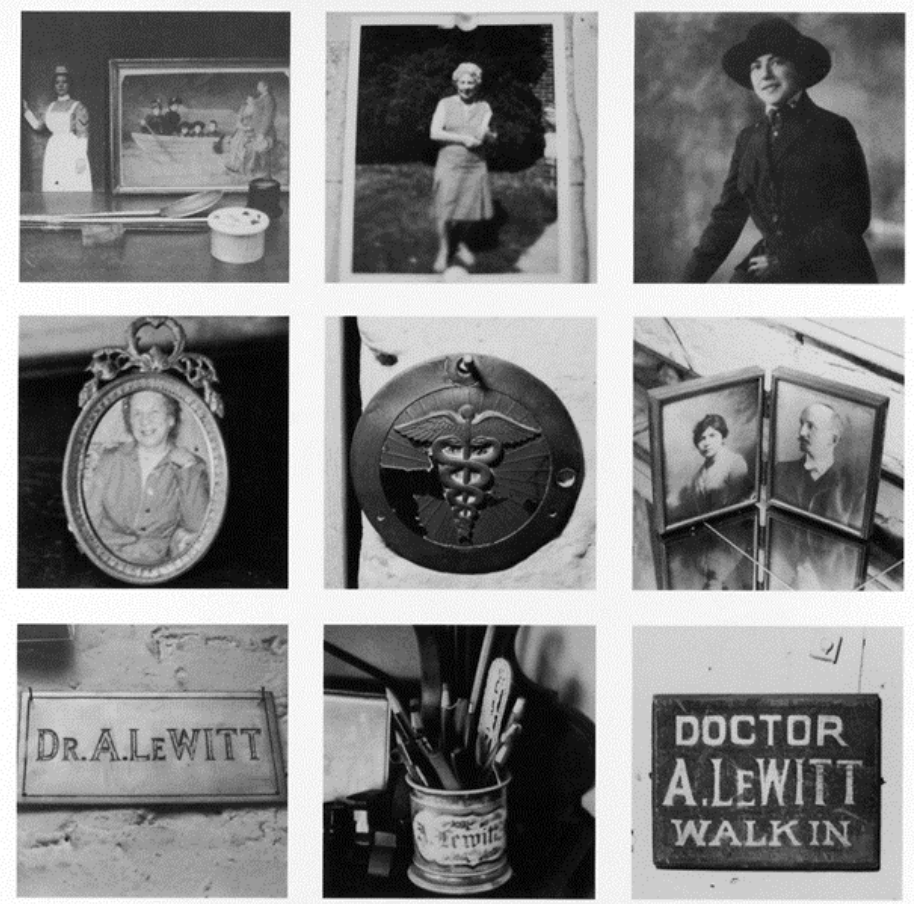

Source: Sol LeWitt, Autobiography, 1980.

\section{Conclusions: The architecture of dwelling}

The Smithson's patio is the mundane complement to the inhabitant's intimacy. It is a piece of the world where a controlled contact with nature is possible; it is the environment where the closest social relations occur, either with family or neighbours, it is the threshold between the public and the private, the previous step in the connection with the Cosmos.

ACE, 15 (44.) CC BY-ND 3.0 ES | UPC Barcelona, España | About Inhabiting: Subjects, Objects and Habitable Space. 
One of the architects who best defines the role of the patio in relation to vital needs is Alejandro de la Sota: "from Pompeii to Mies, not to mention Spain, the courtyard appears: in the interior - if the house allows it - and adjacent, adjoining, built with garden walls - if one cannot afford it. It is such a notorious fact, that of possessing nature notoriously that there is nothing so linked to the landscape as the rural garden wall [...] Within them the intimacy of life, covering the space given by them with vines, creepers, awnings. We will live on every inch of this small piece of land which, in this way, we have converted into the largest of houses. We will live under the protecting vine. [...] We make the house a periscope, a shady terrace to see the far-off sea and mountains" (De la Sota, 1989, p.200).

Between 1983 and 1984, the Spanish architect carried out a housing project in Alcúdia (Majorca), each dwelling organized into two closed bodies comprising bedrooms, kitchen and services, and a central connecting room open to two opposite orientations. To complement the project, De la Sota created a series of freehand perspectives that constitute a rich graphic testimony of architecture's capacity to anticipate and highlight the experiences that its spaces are able to support. One can hear - in the words of Kahn - music through his writing. The spaces represented by De la Sota are precisely this sort of environment with a vocation for semi-covered patios or large atriums open to the sea and mountains. Over them, like the periscope described in the text, rises a terrace open to the four cardinal points, a solarium protected only by a light pergola structure, from which the horizon can be seen (Figure 16).

Figure 16. A. de la Sota. Houses in Alcúdia, Mallorca, 1984

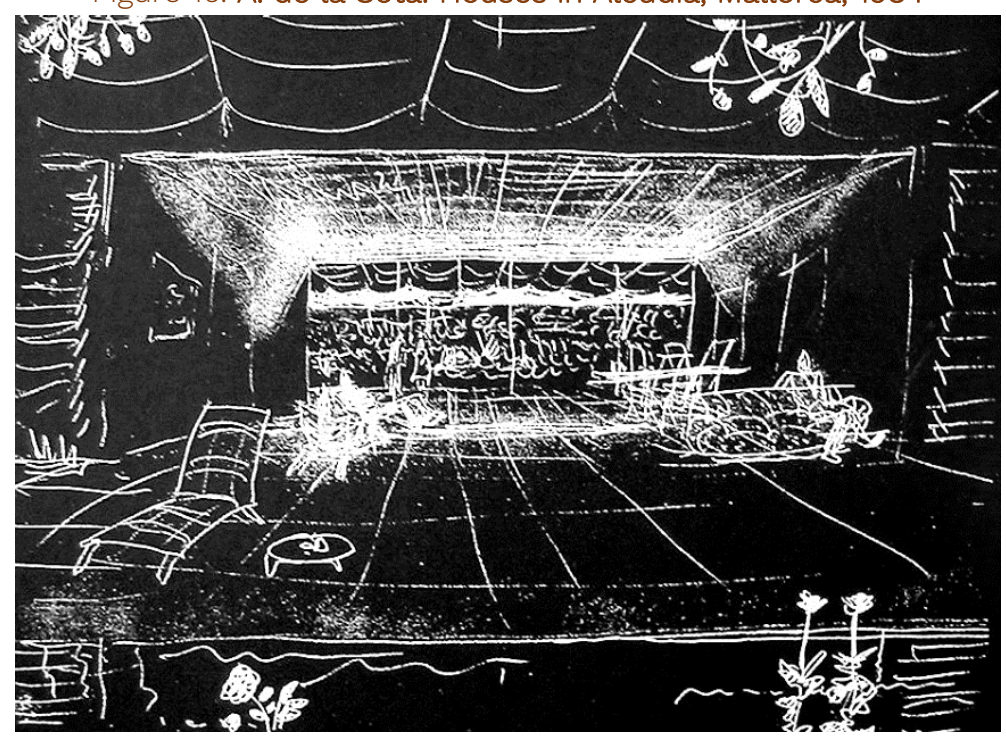

Source: http://archivo.alejandrodelasota.org/

In these perspectives, a number of summer activities are represented: resting time, siesta, conversation, bathing. Contemplating these scenes, one can feel the breeze, the scent of vines, the heat of sunrays or the coolness of shade. Paradoxically, architecture virtually disappears, humbly camouflaged to give way to life, to events, to phenomenon. Architecture - in words of the architect himself - becomes air, "the air we breathe, but an air laden with smells, with wisdom, an air transformed by that very fact, by Architecture" (De la Sota, 1989, p.198).

These spaces drawn by De la Sota are suitable frames in which the changing and variable life unfolds. They are a sort of threshold that for its transient and open condition, allow not only the reaffirmation of subjects but also the intimate and direct relationship with everyday objects, nature and the cosmos. The dualities that, as ingredients, modern architecture uses to formalise space - such as

ACE, 15 (44.) CC BY-ND 3.0 ES | UPC Barcelona, España | About Inhabiting: Subjects, Objects and Habitable Space. 
inside-outside, open-closed, interior-exterior, distant-close, new-old or singular-plural - are here mixed together. Far from being exclusive or independent, they have in the balance their common denominator (Van Eyck, 1999). The environmental conception prevails over the rationality of the space. The temporal experience is the protagonist and architecture should meet its expectations. The rooms, courtyards, thresholds and transition spaces welcome experiences, accumulate moments, evoke memories, and activate objects. They constitute the cradle of human evolution, they are part of it, they complement it and, in turn, they transform it. However, at the same time, the subject provides them with meaning with his presence, through his actions and the perception they receive from him.

These architectures made with 'transformed air', which blend with the events and the environment; respond like an echo to the requirements announced by Heidegger, which prove to be so relevance today. They are placed on the earth, acting as a bridge between sea and mountain, respecting the terrain and dialoguing with nature. They are to be found under the sky, taking advantage of sun and shade, the breeze, the weather phenomena. They lend their empty spaces to the entrance of the divine, favouring an existence beyond the materiality of things. They settle in suitable areas, to live in society with other mortals, opening at the same time their limits to the world and interacting with the outside. Finally, they personalise the essence of construction, according to which "building is really dwelling" (Heidegger, 1954, p.143).

As shown throughout these pages, significant writings and projects produced after the Second World War are a reference for some creations of the last decades, proving that the demand for the human being to occupy the centre of the artistic and architectural debate is completely valid today. In a world that is once again drifting towards overproduction and occupation of territory, the voices of some authors are still being heard. They call for the incorporation of a sustainable humanism into works that have gradually become disconnected from the essential idea that should drive the construction of space: the service to life that it shelters inside.

\section{Authorship}

Both authors have conceptualized and developed this investigation and have written the article.

Conflict of interests: The authors declare that there is no conflict of interest.

\section{Bibliography}

Bachelard, G. (1946). La Terre et les rêveries du repos. Paris, France: José Corti.

Bachelard, G. (1957). La poétique de l'espace. Paris, France: José Corti.

Boudon, Ph. (1971). Sur l'espace architectural : essai d'épistémologie de l'architecture. Paris, France: Dunod Éditeur.

Bucci, F., \& Mulazzani, M. (2000). Luigi Moretti : Opere e scritti. Milano, Italy: Electa.

Campos Uribe, A. et al. (2020). Multiculturalism in Post-War architecture: Aldo van Eyck and the Otterlo Circles. In ACE: Architecture, City and Environment, 14(42), 7033. DOI: http://dx.doi.org/10.5821/ace.14.42.7033

ACE, 15 (44.) CC BY-ND 3.0 ES | UPC Barcelona, España | About Inhabiting: Subjects, Objects and Habitable Space.

DOI: http://dx.doi.org/10.5821/ace.15.44.9054 
Cardiff, J., \& Bures Miller, G. (2007). The Killing Machine i altres histories : Guions. Barcelona, Spain: Col·lecció MACBA.

De la Sota, A. (1989). Alejandro de la Sota, arquitecto. Madrid, Spain: Pronaos.

Giedion, S. (1971). Architecture and the phenomena of transition. The three space conceptions in architecture. Cambridge, MA: Harvard University Press.

Greene, D. (1962). Project. Sprayed plastic house. Archigram, 2, 4-5. Retrieved from http://archigram.westminster.ac.uk

Heidegger, M. (1954). Bauen Wohnen Denken (1951). In Vorträge und Aufsätze (1936-1953). Tübungen, Germany: Günther Neske Pfullingen.

Kahn, L. I. (1961). Talk at the conclusion of the Otterlo Congress 1959. In Neumann, O. New Frontiers in Architecture: CIAM in Otterlo 1959 (p. 205-212). New York, NY: Universe Books.

Kahn, L. I. (1971). The room, the street and human agreement. AlA Journal, 56, 33-34.

Kiesler, F. (1949). Pseudo-Functionalism in Modern Architecture. Partisan Review, 16(7), 733-742.

Kiesler, F. (1966). Inside the endless house. Art, people, and architecture. A journal. New York, NY: Simon and Schuster.

Kohane, P. (2002). The space of human agreement. Louis Kahn and the room. In Universal versus individual. Helsinki, Finland: Alvar Aalto Foundation.

Le Corbusier (1923). Vers une architecture. Paris, France: Crès.

Le Corbusier (1930). Précisions sur un état presént de l'architecture et l'urbanisme. Paris, France: Crès. Le Corbusier (1957). Oeuvre Complète 1946-52. Zurich, Switzerland: Artemis.

Lewitt, S. (1980). Autobiography. New York, NY: Multiples.

Moholy-Nagy, L. (1928). The New Vision: From Material to Architecture. Berlin; Germany: Hans M. Wingler.

Moretti, L. (1952-1953). Strutture e Sequenze di Spazi. Spazio, IV(7), 9-20, 107-108.

Muñoz Millanes, J. (2001). Juan Navarro Baldeweg y sus imágenes. In Navarro Baldeweg, J. La habitación vacante (p. 3-8). Valencia, Spain: Pre-Textos.

Navarro Baldeweg, J. (2001). La habitación vacante. Valencia, Spain: Pre-Textos.

Navarro Baldeweg, J. (2007). Una caja de resonancia. Valencia, Spain: Pre-Textos.

Navarro Baldeweg, J. (2008). La activación de los signos y de los garabatos. Lecture delivered at the Vallès School of Architecture, Universitat Politècnica de Catalunya on 23 October. Sant Cugat del Vallès, Spain.

ACE, 15 (44.) CC BY-ND 3.0 ES | UPC Barcelona, España | About Inhabiting: Subjects, Objects and Habitable Space.

DOI: http://dx.doi.org/10.5821/ace.15.44.9054 
Norberg-Schulz, C. (1971). Existence, Space and Architecture. London, UK: Studio Vista.

Norberg-Schulz, C. (1981). Louis I. Kahn: Idea e immagine. Roma, Italy: Officina Edizioni.

Rasmussen, S. E. (1962). Experiencing Architecture. Cambridge, MA: The MIT Press.

Riegl, A. (1901). Die spätrömische Kunstindustrie nach den Funden in Österreich-Ungarn. Wien, Austria: Österreichische Staatsdruckerei.

Schmarsow, A. (1893). Das Wesen der architektonischen Schöpfung. Lecture delivered at the University of Leipzig on 8 November. Leipzig, Germany: Hiersemann.

Schwarz, R. (1940). Das haus der Christen. Die Schildgenossen, 19(1): 1-17.

Smithson, A., \& Smithson, P. (1994). Changing the art of inhabitation. London, UK: Artemis.

Van de Ven, C. (1978). Space in architecture: the evolution of a new idea in the theory and history of the Modern Movements. Assen. The Netherlands: Van Gorcum.

Van Eyck, A. (1999). Project report of the Hubertus house. Shelter home for single mothers. In Ligtelijn, V. (Ed.), Aldo van Eyck. Works (p. 184-203). Basel, Switzerland: Birkhäuser.

Wogenscky, A. (1987). Les mains de Le Corbusier. Paris, France: Grenelle.

Zevi, B. (1948). Sapere vedere l'architettura: saggio sull' interpretazione spaciale dell' architettura. Torino, Italy: Einaudi.

ACE, 15 (44.) CC BY-ND 3.0 ES | UPC Barcelona, España | About Inhabiting: Subjects, Objects and Habitable Space. 